\title{
Regional Integration as Political Strategy? The Case of China's Economic Offensive against Taiwan*
}

\author{
TONY TAI-TING LIU*
}

This paper analyzes how Beijing attempts to influence other states and achieve its interests through the use of regional integration as an economic instrument. Focusing on the example of China-Taiwan relations (cross-strait relations), this author proposes that China's economic success over the past decade has encouraged the once reclusive country to actively participate in economic integration and market liberalization efforts in East Asia, which in turn translated into strong economic pressure for Taiwan to come to terms with China at the negotiating table. Such a process essentially tips the balance across the Strait in favor of China.

Keywords: China, Taiwan, Regional Integration, East Asia

This paper was presented at the 5th International Association for Asia Pacific Studies (IAAPS) Annual Conference, Incheon, South Korea, November 27-28, 2014. Parts of this draft were completed in Tokyo under the generous support of the Interchange Association of Japan.

** Doctoral Candidate, National Chung Hsing University, Taiwan;

E-mail: stanggoftibia1984@yahoo.com.tw;

DOI: $10.16934 /$ isr.16.1.201506.25 


\section{INTRODUCTION}

Since Deng Xiaoping's adoption of open reforms in 1979, the international community has witnessed the growth and development of China into an economic power. Fueled by rapid growth, China has not only become an economic power over the past decade, it has also come to exert more influence on both the global and regional levels. On the path towards great power status, China's leadership has repeatedly emphasized the need for China to secure a surrounding environment that is favorable for the country's continued development. Beginning in the $\mathrm{Hu}$ Jintao era, terms such as "peaceful rise," "peaceful development," and "harmonious worldview" were subsequently introduced by political elites, in an attempt to reassure other states that China's rise is not a phenomenon that entails a disrupttion of, or a challenge to, the global order (Tsai et al. 2011, 28).

While many neighboring states in East Asia continue to maintain stable and steadily growing economic relations with China, in many respects China's rise remains unsettling, particularly in terms of geopolitics. Besides a military budget that increased in parallel with economic growth over the past decade, China has become more assertive and aggressive in the region. For example, although China's trade with ASEAN countries grossed over tenfold over the past decade, territorial disputes continue to strain relationship between China and Southeast Asia. In 2010, regarding controversies over the South China Sea, Beijing proclaimed to other parties that the region is a "core interest" of China that cannot be contested (Yoshihara and Holmes 2011). In 2015, regardless of continued disputes among claimants to territorial sovereignty in the region, China became more aggressive towards protecting its core interest by carrying out land reclamation efforts in the Spratly Islands (Tiezzi 2014).

Indeed, when words and actions from Beijing are placed beside one another, the implications of China's rise become questionable. In terms of bilateral relations, the Japanese term seireikeinetsu or "cold political relations and hot economic relations" captures the relationship of many states with China. As the case of Southeast Asia demonstrates, while economic relations between China and ASEAN expanded, the South China Sea remained a barrier to improved relations among the parties. Another Japanese term seikeibunritsu or literally "the separation between politics and economics" describes the way many states maintain their relationship with China. While the issue of South China Sea persists, trade between China and Southeast Asia continues; geopolitics and economics should be set apart as two different realms bearing no necessary connections. Yet how viable are such claims?

Noting the claim of seikeibunritsu, this author argues that in contrast to the desire of many states to treat political and economic relations distinctly, China is linking the realms of politics and economics and often seeks to achieve its political interests by exploiting economic tools at its disposal. In other words, China is 
attempting to do the opposite. This paper is an observation of how Beijing attempts to influence other states and achieve its interests through the use of regional integration as an economic instrument. Focusing on the example of China-Taiwan relations (cross-strait relations), this author proposes that China's economic success over the past decade has encouraged the once reclusive country to actively participate in East Asian economic integration and market liberalization efforts, which in turn translate into strong economic pressure for Taiwan to come to terms with China at the negotiating table. Such a process essentially tips the balance across the Strait in favor of China.

The observation of Beijing's strategy is carried out in four parts. Part 1 provides a general overview of China's economic rise since the turn of the century. Part 2 elaborates on China's expanding role in regional integration as a result of its changing status. Part 3 reviews the political economics of cross-strait relations and describes how China's regional integration strategy could serve as an instrument to pressure Taiwan into addressing political questions. Finally, Part 4 reflects on the implications of China's new found economic power.

\section{CHINA'S ECONOMIC RISE}

China's economic rise is arguably one of the most important phenomena of the new century. New York Times reporter Nicholas Kristof (1993, 62-63) recognized the phenomenon as early as 1993 and pointed out that China was growing at an approximate rate of 9\% per annum. Figure 1 shows the trend of China's economic growth since 2000, with growth accelerating in 2002 and recording double digits for five straight years from 2003 to 2007.

FIGURE 1. CHINA REAL GDP GROWTH 2000-2013 (\%)

\begin{tabular}{cccc}
\hline Year & GDP Growth & Year & GDP Growth \\
\hline 2000 & 8.4 & 2007 & 14.2 \\
\hline 2001 & 8.3 & 2008 & 9.6 \\
\hline 2002 & 9.1 & 2009 & 9.2 \\
\hline 2003 & 10.0 & 2010 & 10.4 \\
\hline 2004 & 10.1 & 2011 & 9.3 \\
\hline 2005 & 11.3 & 2012 & 7.7 \\
\hline 2006 & 12.7 & 2013 & 7.7 \\
\hline
\end{tabular}

SOURCE: The World Bank, "GDP Growth," http://data.worldbank.org/indicator/NY.GDP.MKTP.KD.ZG.

In 2010, China surpassed Japan to become the second largest economy in the world and the largest economy in Asia. Adjusted for purchasing power, China stands as the second largest economy in the world after the US with USD 9.872 
trillion in GDP (2010) (WTO 2011). China's total export has grown from USD 1,400 million in 2005 to over USD 1,500 million in 2010 (WTO 2011). Regardless of debates, in 2014, according to statistics provided by the International Monetary Fund (IMF), the Chinese economy edged out the US (USD 17.4 trillion) to become the largest economy in the world at USD 17.6 trillion (Duncan and Martosko 2014).

Although the long-term growth of China's economy remains unpredictable, the country's economic performance has already caused observers such as Noble laureate Joseph Stiglitz (2015) to tout the twenty-first century as the Chinese century. Besides growth, China's economic power is also reflected in other aspects. For example, in terms of foreign exchange reserves, or the holding of gold and other convertible foreign currencies, China leads the world with USD 3899 billion, a figure that largely reflects the country's surplus trade. In terms of foreign direct investment (FDI), in 2013, the Chinese market attracted USD 123,911 million, a figure topped only by the US (USD 187,528 million) and led the next largest market, Russia, by more than a margin (UNCTAD 2014; Arnett 2014). Another indicator of China's new wealth can be found in the amount of official development aid (ODA) that Beijing provides to other countries. According to a comparative study by Kitano and Harada (2015), Chinese ODA was estimated to reach USD 7.1 billion in 2013, a figure that transformed China into one of the largest donors in the world.

\section{CHINA'S GROWING ROLE IN EAST ASIA ECONOMIC INTEGRATION}

While the economic indicators mentioned in the previous section reflect China's economic prowess, one should also note the growing confidence and ambition Beijing has established on top of its wealth. An often cited example that demonstrates growing confidence from Beijing is China's increased presence in Africa (Brautigam 2011), a status mainly realized with the provision of foreign aid and assistance to the continent. A less noted case is China's increased engagement with East Asia, most notably through economic integration. One may be surprised to learn that as late as the early years of the post-Cold War period, China remained passively engaged with Asia. Besides joint studies carried out by the Chinese academia on the possibilities of transnational cooperation on the local level, Beijing seemed dispassionate about regional integration. In contrast to Japan, Korea, Indonesia and others, China was not among the original members of Asia-Pacific Economic Cooperation (APEC) and did not participate in the initiative until two years after its establishment in 1989.

Nonetheless, a growing economy eventually encouraged China to increase its participation in regional economic integration. Such a development partly stemmed from Japan's economic decline beginning in the late 1980s, which left a regional 
power vacuum and Asia without an economic leader. In 1997, the outbreak of the Asian Financial Crisis provided an opportunity for the region to correct the situation. By maintaining the exchange rate of the renminbi, China prevented hard hit countries in Southeast Asia such as Thailand, Indonesia, Malaysia and the Philippines from further economic distress. Coupled with a rising economy, China's action pushed Beijing into the driver seat of East Asia (Liu and Tsai 2014). In contrast with its isolationist stance in the immediate post-Cold War period, currently, China not only participates in a number of completed integration projects and ongoing negotiations, it has also taken up new initiatives that provide alternative schemes for neighboring states. Three initiatives are worth considering: the ASEAN plus, the China-Japan-Korea Free Trade Area (CJKFTA), and the Free Trade Area of the Asia Pacific (FTAAP).

\section{ASEAN Plus}

Besides setting the stage for the emergence of China's leadership in East Asia, the Asian Financial Crisis also provided the momentum for the establishment of the ASEAN Plus Three (APT) mechanism. As APEC failed to provide any answers to the financial crisis (Cheng 1998, 22), the APT came to serve as a meaningful alternative for regional integration. Composed of 10 states in Southeast Asia and China, Japan and Korea, the APT became the dominant model for East Asia regional integration in the new century. In 2005, with the participation of Australia, New Zealand and India, APT expanded to six extra-regional members outside Southeast Asia. The ASEAN Plus Six would become the foundation for the Regional Comprehensive Economic Partnership (RCEP) advocated by ASEAN in 2012.

Since its inception in 1997, the APT has served as China's main channel for realizing regional integration. Besides the establishment of APT, the ASEAN Plus One (APO) mechanism that involves separate cooperation between ASEAN and China, Japan and Korea was also the 1997 APT summit. As progress in the APT gradually slowed down after its initial drive, momentum shifted to the APO. In 2002, after several rounds of joint consultations, China and ASEAN concluded the Framework Agreement on ASEAN-China Comprehensive Economic Cooperation, a legal instrument that would become the foundation for the establishment of a free trade area between China and Southeast Asia (Sheng 2003). In 2010, the ASEAN-China Free Trade Area (ACFTA) was officially realized, becoming the largest regional integration initiative in East Asia to date ( $\mathrm{Li}$, Wang and Whalley 2014). In terms of population, the ACFTA is the largest FTA in the world while trailing only NAFTA and the EU in terms of GDP. The completion of ACFTA encouraged both China and ASEAN to pursue further integration through the RCEP framework in 2012. Currently, parties to the RCEP have completed seven 
rounds of negotiations and intend to realize the partnership by the end of 2015 .

\section{China-Japan-Korea Free Trade Area}

In 1999, in a separate breakfast meeting hosted during the APT summit in the Philippines, Chinese Prime Minister Zhu Rongji, Japanese Prime Minister Keizo Obuchi and South Korean President Kim Dae-jung convened for discussions on pushing forward cooperation in East Asia. The informal summit in the Philippines eventually became the precursor for the China-Japan-Korea Summit to be held alongside the annual APT summit. After the organization of several rounds of talks through the APT framework, in 2008, CJK leaders conducted the first Trilateral Summit independent of the APT and began the process of institutionalizing the relationship. Since 2008, CJK leaders have carried out five rounds of discussions through the Trilateral Summit, with the most recent meeting held in 2012 before tensions among China, Japan and Korea severed further talks.

In terms of regional integration, the commencement of trilateral cooperation in 1999 also established an improved atmosphere for economic advancement. At the annual APT summit in 2001, Chinese PM Zhu Rongji officially proposed the idea of establishing a Northeast Asia free trade area consisting of China, Japan and Korea (Lee 2014, 172). With the adoption of the "Action Strategy on Trilateral Cooperation" in 2004 by CJK, interest in the establishment of CJK FTA picked up. In late 2009, CJK leaders reached an agreement that a tripartite study group on CJK FTA including government officials should be convened. A formal Joint Study Committee was launched in May 2010, concluding its work in a Joint Study Report in December 2011. Since the launch of negotiations in 2013, five rounds have been carried out. Despite political tensions, CJK seek to complete negotiations by 2015 .

\section{Free Trade Area of the Asia Pacific}

On the occasion of the 2014 annual APEC summit in Beijing, China's President Xi Jinping called for members to the meeting to support the establishment of a Free Trade Area of the Area Pacific (FTAAP). Xi's proposal came as a surprise, as Asia is currently not without other economic cooperation initiatives such as the RCEP and TPP. Yet the announcement is significant in that China is attempting to revive APEC's traditional purpose on promoting and deepening economic cooperation in the Asia Pacific region. On the other hand, it is interesting to note that FTAAP was originally endorsed by the US George W. Bush administration as the potential initiative for realizing regional integration in Asia. China's reiteration of FTAAP entails strategic implications that remain to be observed in the near future. $^{1}$ 


\section{REGIONAL INTEGRATION AS POLITICAL STRATEGY? THE CASE OF CHINA'S LATENT OFFENSIVE AGAINST TAIWAN}

Even though Chinese officials have never admitted to the adoption of regional integration as a political strategy, one can nonetheless observe many delicate processes at work. In light of its expanding role in regional economic integration, there are several ways for China to exploit such progress for political interests.

First, conditional upon continued economic growth, Beijing's role in regional integration may expand in parallel, to the extent that China becomes the indispensable center of economic integration in East Asia. Once China achieves such status, issue linkage may be used as a tactic by Beijing to secure interests beyond economic gains.

Second, as China extends its participation to various regional integration projects and increases its role in respective projects based on economic status, many states may soon find themselves enmeshed in a network of initiatives centered on China. Located within the network, a state becomes susceptible and vulnerable to Beijing's demands unless it withdraws or finds a way to balance China.

Third, in the case of an initiative established or headed by China with strong support, Beijing enjoys the privilege of agenda setting. In short, to a certain extent, regional integration holds implications beyond simple economic calculations. The following sections examine the case of cross-strait relations and seek to demonstrate how China's participation in regional integration efforts has turned into an economic offensive against Taiwan.

\section{The Political Economy of Cross-strait Relations}

Since the separation of China into two autonomous regions in 1949, the economic relationship between China and Taiwan became a function of the political atmosphere across the Taiwan Strait. As Wei (2009) points out, cross-strait economic relations can be generally divided into five periods: strict forbiddance and no contact prior to 1987; indirect trade exchange from 1987 to 1992; institutionalization from 1992 to 1996; development from 1996 to 2008; and direct trade exchange since 2008. The progress in economic relations across the Strait has largely evolved parallel to political relations between Beijing and Taipei. For example, in 1992, China and Taiwan agreed on the so called "1992 Consensus," an agreement that notes the recognition of the One China principle by both Beijing and Taipei but refrains from providing a precise definition of China. The consensus paved the way for further contact across the Strait in 1993, when Beijing and Taipei carried out their first official dialogue since 1949 through the para-official organizations Association for Relations across the Taiwan Strait (ARATS) and Strait Exchange Foundation (SEF). 
In 1996, cross-strait relations retreated to a trough reminiscent of the Cold War when China fired missiles across the Strait in an attempt to influence Taiwan's first democratic presidential election (Ross 2000; Whiting 2001). Since then, relations between China and Taiwan fell into a retreat marked by the severance of official communication between ARATS and SEF and fierce diplomatic competition. In 2000, Taiwan underwent its first party transition in government with the election of Democratic Progressive Party (DPP) candidate Chen Shui-bian. A zero sum outlook soon dominated cross-strait relations under the DPP, as Taipei and Beijing became engrossed in an intense game of competing for diplomatic recognition (Rich 2009; Erikson and Chen 2007). Although economic interaction between China and Taiwan continued, an uncertain atmosphere shrouded cross-strait relations. In response to the China threat, Taiwan made an effort to stop the "moving west" (xijin) of investments in this period, commencing from policies such as "no haste, be patient" (jiejiyongren) under Lee Teng-hui to "proactive liberalization with effective management" and "proactive management with effective liberalization" under Chen Shui-bian.

Relations between China and Taiwan did not improve again until 2008 (after a 10 year hiatus) when Taiwan underwent its second party transition in government with the election of Nationalist Party (KMT) candidate Ma Ying-jeou. Cross-strait relations commenced afresh, as Taipei and Beijing reinitiated dialogue between ARATS and SEF that had been terminated since 1999. Under the new administration, political tensions relaxed and relations across the Strait changed significantly. Besides the call for "diplomatic truce" (waijiao xiubing) and a halt to race to the bottom "checkbook diplomacy" between China and Taiwan (Huang 2009), the Ma administration endorsed "flexible diplomacy" (tanxing waijiao), a pragmatic strategy that aims to increase Taiwan's international recognition and foreign policy space with an understanding of the unique status of the country in the world (Huang 2012).

China responded favorably to Taiwan's good will. Since 2008, Taiwan has not lost a single diplomatic relation due to competition with China. Indeed, as the political atmosphere shifted across the Strait, "economics" became the dominant keyword as both Taipei and Beijing agreed to leave politics aside in search of progress or win-win between the two countries. Besides completion of the Three Linkages (Santong), in the fifth round of Jiang-Chan Talks in 2010, ${ }^{2}$ Taiwan and China signed the Economic Cooperation Framework Agreement (ECFA), a trade liberalization agreement that takes into account the special situation of cross-strait relations. For many observers (Liao 2013; Liu 2011; Pang 2011), ECFA seemed to be the break Taiwan needs to re-connect with Asia and fulfill the role of a trading hub in the region.

In 2012, Ma defeated DPP presidential candidate Tsai Ing-wen and remained in office as the President of Taiwan. Across the Strait, Xi Jinping replaced $\mathrm{Hu}$ 
Jintao as China's new president. While cross-strait relations do not show signs of retreat under $\mathrm{Ma}$ and $\mathrm{Xi}$, strong undercurrents have developed as Beijing hints at the "final solution" in cross-strait relations. As Xi expressed at the 2013 APEC Summit in Bali, Indonesia, "in the long term, the political division across the Strait should be gradually resolved; we cannot leave these problems for generations without end." ${ }^{3}$ Although Xi has yet to set a schedule for political resolution between China and Taiwan, ${ }^{4}$ increasing imbalance that stems from China's rise and Taiwan's economic stagnation has observers such as John Mearsheimer (2014) and Hugh White (2015) pondering the possibility of Taiwan ceasing to exist.

\section{China's Latent Offensive and Taiwan's Challenge}

Besides trade, in terms of cross-strait relations, the issue of regional integration can also be a function of political relations between China and Taiwan. When political relations were tense, integration stagnated; when the political atmosphere was relaxed, integration showed progress. A clear example portraying such dynamics is the different success the DPP and KMT governments enjoyed in the pursuit of economic cooperation and integration with China. While the Chen Shuibian administration struggled to keep local business interests from crossing the Strait and failed in developing any form of economic cooperation with Beijing, since 2008, the Ma Ying-jeou administration subsequently completed ECFA and the Cross-strait Service Trade Agreement with Beijing, commencing the integration of Taiwan with China.

Yet it is worthwhile recognizing that cross-strait relations develop within the larger backdrop of East Asian regional integration. The economic integration of Taiwan and China is merely a set of developments amidst ongoing bilateral and multilateral integration projects such as the ACFTA, CJKFTA, RCEP and FTAAP. While the initiatives may be understood separately, taken together, China's ubiquitous presence in all integration projects hint at a much larger strategic effort (Jin 2013). As Tsai Tung-chieh $(2011,121)$ points out, as its international status elevates, China will seek to gradually integrate countries in its vicinity into an economic entity centered on Beijing as a strategic step towards establishing leadership in East Asia.

In terms of Taiwan, regardless of whether Beijing's strategy is aimed at isolating Taipei or not, China's challenging effects for the latter are clear. Standing outside East Asia's integration process in the first place, Taiwan has the need and urgency to participate in regional integration. Yet China's growing presence in East Asian integration generates real difficulties for Taiwan. While political sensitivities such as the One China principle seem to forever undermine Taiwan's potential for participating in international affairs, China's increased participation exacerbates the situation. China's increased interest in regional integration and its 
presence in nearly all the major multilateral integration initiatives in East Asia leave little options for Taiwan but to engage with Beijing. As an existing member to the various initiatives, China holds the advantage of establishing conditions for the entry of non-member states such as Taiwan, a favorable position that could be used easily for making other demands.

Preconditioned upon China's continued economic growth and interest in regional integration, Beijing's integration strategy becomes a latent offensive against Taiwan from a certain respect. As China grows, its status in regional integration initiatives is likely to expand as well, giving Beijing a stronger voice and more influence in East Asia, and a greater say in the direction of regional integration. Both the RCEP and FTAAP are examples of China's growing leadership in regional integration. As the various integration initiatives in East Asia move forward, even without China making an explicit effort to block the participation of Taiwan, the latter will face mounting pressure to confront Beijing and its accompanying demands, including the possibility of political demands. In a sense, as China's role in regional integration increases as a result of its expanding economic power, regardless of political sensitivities, Taiwan will increasingly find itself caught in the situation of needing to deal with China or risk continued isolation from regional integration, a choice that entails serious consequences. Although the choices may seem like separate issues at first glance, China's central role in East Asia regional integration establishes linkages between the options. For both China and Taiwan, the politics of cross-strait relations carry over to regional integration and cause the latter to become a function of politics.

Since the formal launch of RCEP negotiations in 2012, China has been a strong supporter of the initiative (Zhao 2014, 6). As the first country to realize an FTA with ASEAN, China enjoys great political advantage in Southeast Asia. Although Taiwan has repeatedly expressed its interest in joining the RCEP, its hopes remains dashed as parties to the negotiations remain silent on their support for Taiwan. Meanwhile, as Bonnie Glaser $(2013,28)$ observes, nothing substantive has been agreed upon since Honorary KMT Chairman Wu Poh-hsiung's direct communication to Chinese President Xi Jinping of Taiwan's desire to join the RCEP. In 2014, Deputy Minister of Taiwan's Mainland Affairs Council (MAC) Lin Chu-chia issued a statement calling for "joint studying" of the potential for further economic cooperation between China and Taiwan for the larger goal of regional integration (Wang 2014). Once again, Beijing has not responded. While progress towards Taiwan's participation in regional integration remained slow, China has continued to release statements that call for political negotiations.

In short, in terms of regional integration, China's heightened regional role and presence creates three challenges for Taiwan. First, as China gradually establishes its leading economic role in Asia, Taiwan may find the regional terrain increasingly difficult to navigate without coming across China. Second, as China 
strengthens its role in regional integration projects, Taiwan may be challenged with the realization that few alternatives exist in which dealing with China is not a necessity. In both instances, Beijing's omnipresence contains the potential for issue linkage between political demands and economic interests. Finally, with the high probability of Taiwan's participation in regional integration occurring under an initiative led by China, Taiwan may need to consider the possibility of an agenda largely dominated by Chinese interests. While Beijing may not use multilateral settings as proper channels for treating cross-strait relations, issue linkage across channels remains a possibility and potential challenge.

\section{CONCLUSION: THE IMPLICATIONS OF CHINA'S ECONOMIC POWER}

While Taiwan may be a unique case that demonstrates China's new economic power due to the island's special international status and political relationship with China, upon closer observation several insights can nonetheless be realized.

First, China's growing role in East Asia regional integration entails the potential for issue linkage. The fact that China's economic rise coincided with the takeoff of regional integration in East Asia turns the latter into an instrument that Beijing can exploit towards the advancement of its national interest. In terms of cross-strait relations, Beijing has effectively established regional integration as an issue that cannot be easily separated from political considerations. If the same logic is extended to other states, particularly in East Asia, then Taiwan's politicaleconomic dilemma may be replicated as well.

Second, China's increasing regional role may continue to give rise to conflict and rivalry from states that are discontent with such development. Although China's expanding influence greatly curtails Taiwan's policy options in East Asia, especially in terms of regional integration, the same may not be true for states that have options other than moving closer to China. While China continues to push for the RCEP, across the Pacific the US places its support in the Transpacific Partnership (TPP), an alternative integration initiative for Asia. The overlapping scope of the RCEP and TPP has led to an interpretation of the projects as just another aspect of great power competition between China and the US. With another policy option in the TPP, how states caught in the competition, particularly in Southeast Asia, may respond to China's effort to assert its regional economic dominance remains an open question.

\section{REFERENCES}

Arnett, George. 2014. Foreign direct investment: which countries get the most? http://www.theguardian.com/news/datablog/2014/jun/24/foreign-direct-inves 
tment-which-countries-get-the-most.

Brautigam, Deborah. 2011. Chinese Development Aid in Africa: What, Where, Why and How Much? In Rising China: Global Challenges and Opportunities, eds. Jane Golley and Ligang Song. Canberra: Australia National University Press.

Cheng, Tun-jen. 1998. APEC and the Asian Financial Crisis: A Lost Opportunity for Institutional Building? Asian Journal of Political Science 6(2): 21-32.

Chien-kuo Pang. 2011. ECFA hou liangan changye hezuo zhanwang: zhengzhi jingjixue de fenxi (The Prospects for Industrial Cooperation across the Taiwan Strait in the Post-ECFA Era: A Political Economy Analysis). Guojia Fazhan Yanjiu (Journal of National Development Studies) 11(1): 43-95.

China APEC Development Council. Asia-Pacific Economic Cooperation. http:// www.chinaapec.org/en/about_apec/.

Chunding, Li, Jing Wang. and John Whalley. 2014. China's Regional and Bilateral Trade Agreements. NBER Working Paper 19853.

Duncan, Hugo and David Martosko. 2014. America usurped: China becomes world's largest economy-putting USA in second place for the first time in 142 years. http://www.dailymail.co.uk/news/article-2785905/China-overtakes-U-S-worlds-largest-economy-IMF-says-economy-worth-17-6trillion-America-falls-se cond-place-time-1872.html.

Erikson, Daniel and Janice Chen. 2007. China, Taiwan, and the Battle for Latin America. The Fletcher Forum of World Affairs 31(2): 69-89.

Glaser, Bonnie. 2013. Taiwan's Quest for Greater Participation in the International Community: A Report of the CSIS Freeman Chair in China Studies. Lanham: Rowman and Littlefield.

Harold, Scott. 2013. The Chinese Perspective. In Joint US-Korea Academic Studies, Asia's Uncertain Future: Korea, China's Aggressiveness, and New Leadership, ed. Gilbert Rozman. Washington DC: Korea Economic Institute of America. 24.

Huang, Kwei-bo. 2009. cong linghe zou xiang shuangying: wo guo huoluwaijiao de zhanlue zhuanzhe (From 'Zero Sum' to 'Win-Win': Taiwan's Strategic Turn towards Viable Diplomacy). In Mazongtong Zhizhenghou de Liangan Xinju: Lun Lianganguanxi Xinluxiang (New Prospects under the Ma Administration: On New Directions in Cross-strait Relations), eds. Chao-Ming Tsai. Taipei: Prospect Foundation.

Huang, Kwei-bo. 2012. Participation internationale de Taiwan: Avancées et limites de la diplomatie flexible. Politique Internationale 138.

Jin, Jianmin. 2013. China's Asian Economic Integration Strategy: FTA, RCEP, TPP. Fujitsu Research Institute Research Report 412.

Kitano, Naohiro and Yukinori Harada. 2015. Estimating China's Foreign Aid 2001-2013. Journal of International Development (forthcoming). 
Kristof, Nicholas. 1993. The Rise of China. Foreign Affairs 72(5): 59-74.

Lee, Szu-hsien. 2014. zhongrihan ziyoumaoyiqu de xingcheng keneng (NEAFTA: The Reason Why It Will be Come True or Not). Jiayi Daxue Tongshi Xuebao (General Education Journal of National Chiayi University) 11: 163-185.

Li, Jing. Tough Times Ahead for China-Japan-South Korea Joint FTA. http:// www.eastasiaforum.org/2014/12/06/tough-times-ahead-for-china-japan-southkorea-joint-fta/.

Liao, Shunyo. 2013. lun ECFA yu liangan huxin jizhi zhi jiangou (ECFA and Confidence Building Measures across the Taiwan Strait). Quanqiu Zhengzhi Pinglun (Review of Global Politics) 41: 115-132.

Liu, Weng-kun. 2011. liangan jingji hezuo jiagou xieyi dui Taiwan de zhengjing yinxiang ji weilai zhanwang (The Effects of Economic Cooperation Framework Agreement (ECFA) on Taiwan's Politics and Economy, and the Future Prospects). Dongya Luntan Jikan (East Asia Review) 472: 9-20.

Mearsheimer, John. 2014. Say Goodbye to Taiwan. http://nationalinterest.org/arti cle/say-goodbye-taiwan-9931.

Rich, Timothy S. 2009. Status for Sale: Taiwan and the Competition for Diplomatic Recognition. Issues and Studies 45(4): 159-188.

Ross, Robert S. 2000. The 1995-1996 Taiwan Strait Confrontation: Coercion, Credibility, and the Use of Force. International Security 25(2): 87-123.

Sheng, Lijun. 2003. China-ASEAN Free Trade Area: Origins, Developments and Strategic Motivations. ISEAS Working Paper: International Politics and Security Issues Series 1.

Stiglitz, Joseph. 2015. The Chinese Century. http://www.vanityfair.com/news/20 15/01/china-worlds-largest-economy.

Tiezzi, Shannon. 2014. Why is China Building Islands in the South China Sea? http://thediplomat.com/tag/south-china-sea-land-reclamation/.

Tsai, Tung-Chieh and Tony Tai-Ting Liu. 2013. Whither East Asian Regionalism? China's Pragmatism and Community Building Rhetoric. Japanese Journal of Political Science 14(4): 543-566.

Tsai, Tung-chieh, Ming-Te Hung, and Tony Tai-Ting Liu. 2011. China's Foreign Policy in Southeast Asia: Harmonious Worldview and Its Impact on Good Neighbor Diplomacy. Journal of Contemporary Eastern Asia 10(1): 25-42.

Tsai, Tung-Chieh. 2011. Dangdai Zhongguo Waijiao Zhengce (China's New Diplomacy: Interpreting Its Connotation and Tendency). Taipei: Wunan.

UNCTAD. 2014. FDI Overview: China. http:/unctad.org/sections/dite_dir/docs/ wir2014/wir14_fs_cn_en.pdf.

Wang, Zhao-kun. luweihui: liangan gongtong yanjiu youzhu tai ru RCEP (Mainland Affairs Council: Joint Studies across the Strait Will Help Taiwan in Entering RCEP). http://www.rti.org.tw/m/news/detail/?recordId=127247.

Wei, Ai. 2009. jingji quanqiuhua xia liangan jingmao guanxi de zhanlue xuanze 
(The Strategic Options of Cross-strait Economic Relations under Economic Globalization). Haixia Pinglun (Strait Review) 217.

White, Hugh. The Harsh Reality that Taiwan Faces. http://www.straitstimes.com/ news/opinion/invitation/story/the-harsh-reality-taiwan-faces-20150415.

Whiting, Allen. 2001. China's Use of Force, 1950-96, and Taiwan. International Security 26(2): 103-131.

WTO Statistics Database (Trade Profiles: China). http://stat.wto.org/CountryPro file/WSDBCountryPFView.aspx ? Language $=\mathrm{E} \&$ Country $=\mathrm{CN}$.

Yoshihara, Toshi and James R. Holmes. 2011. Can China Defend a 'Core Interest' in the South China Sea? The Washington Quarterly 34(2): 45-59.

Zhao, Hong. China's Evolving Views on the TPP and the RCEP. http://www.iseas. edu.sg/documents/publication/iseas_perspective_2014_28_china_evolving_v iews_on_the_tpp_and_the_rcep.pdf. 


\section{ENDNOTES}

1 Solis offers a good analysis of the strategic implications of China's adoption of the FTAAP. See: Mireya Solis, "China Flexes its Muscle at APEC with the Revival of FTAAP," http://www.eastasia forum.org/2014/11/23/china-flexes-its-muscles-at-apec-with-the-revival-of-ftaap/.

2 The three linkages refer to the opening of direct communication between China and Taiwan, which includes direct flights, direct shipping and direct exchange of mail across the Taiwan Strait.

3 "Xi Jinping: liangan zhengzhi fenqi wenti zhonggui yao jiejue," (Xi Jingping: Political Problems in Cross-strait Relations should be resolved in the end), http://news.sina.com.hk/news/20131006/-93083454/1.html.

4 "Xi Jinping queli lianganguanxi luxiantu" (Xi Jinping confirms the path ahead for Cross-strait relations), http://hkmag.crntt.com/crn-webapp/mag/docDetail.jsp?coluid=81\&docid $=102842572$. 